\title{
Analysis of Professional Dispositions Taught to Prospective Teachers in Public Sector Universities of Punjab
}

\author{
* Muhammad Riaz, PhD Scholar (Corresponding Author) \\ ** Dr. Muhammad Uzair ul Hassan, Associate Professor
}

\begin{abstract}
Due to the importance of dispositions, the National Accreditation Council for Teacher Education (NACTE) in Pakistan like many other countries of the world has included dispositions in its standards. NACTE also entails that teacher-training institutes are responsible to develop and impart dispositions among pre-service teachers. The current study analyzed the professional dispositions taught to prospective teachers at public sector universities of Punjab. The quantitative survey research design was employed to accomplish the study. The accessible population of the study was 1592 teacher-candidates of the final semester of BS/B. Ed. Honors in Education and M. A. Education programs. The sample was selected through multi-stage sampling. A questionnaire was developed for data collection keeping in view the dispositions described in the document of National Professional Standards for Teachers in Pakistan (NPSTP). The study concluded that dispositions related to the categories "moral values and commitment to students' learning" are being taught in the public universities to a greater extent as compared to other categories. The study also concluded a positive correlation between dispositions taught to prospective teachers and academic achievements (CGPA). Researchers recommend that policymakers may introduce a core subject based on professional dispositions having more dispositions-oriented content, so as to produce effective teachers for future needs of the educational institutes of Pakistan.
\end{abstract}

Keywords: Professional Taught Dispositions, Teacher-training Institutes, Teaching Programs, Prospective Teachers.

\section{Introduction}

Quality of teachers is associated with the quality of teacher education institutes because teachers are equipped with all necessary knowledge, theories, teaching skills, professional dispositions and required training in these institutes. Therefore, throughout the world, institutions for teacher training are applying and searching ways for the preparation of their upcoming teachers to meet the needs and challenges of today's diversified students more effectively. According to Notar, Riley, Taylor, Thornburg and Cargill (2009), many researchers have discovered a strong positive relationship between dispositions of teachers and students' learning and performance. Taylor and Wasicsko (2000) also concluded that a strong correlation exists between teachers' dispositions and effectiveness. According to Anderson, Christenson, Sinclair and Lehr (2004), students whom homes' environment outspokenly differ from schools' environment, need to have a very strong bonding with teachers, school and other staff members in the school. This strong bonding could be established by only those teachers who are well trained and have professional dispositions.

Professional dispositions help future teachers in creating an environment in which they can apply the teaching strategies and theories suggested to effective teachers (Wayda \& Lund, 2005). Consequently, many educational researchers have recommended that teachers' dispositions are equally important along with content knowledge and teaching skills to help the students in their learning process. According to Parrott, Ros-Voseles, Denise and Eaton (2013), teachers who have professional dispositions demonstrate a higher level of self-efficacy as compared to those teachers who do not have professional dispositions. These teachers always accept constructive and positive criticism and try to use new and innovative teaching strategies to enhance the teaching-learning environment in the classroom.

* Department of Education, University of Sargodha, Sargodha Email: mianriaz90@gmail.com

** Department of Education, University of Sargodha, Sargodha Email: uhassan74@ gmail.com 
According to Shoffner, Sedberry, Alsup and Johnson (2014), most of the teaching skills, beliefs and behaviors related to teaching are being articulated through teacher education programs as a result of desired outcomes to develop pre-service teachers' dispositions. Even though it is quite difficult to develop and assess such kind of development of dispositions among prospective teachers. However, Shoffner et al., (2014) argued that in spite of difficulties and problems in developing dispositions, teacher educators agreed in developing the dispositions due to its importance. They also concluded since dispositions help in guiding the prospective teachers' tendencies for acting in a particular way therefore, prospective teachers must be aware of professional dispositions. Prospective teachers can apply the theories, teaching skills and dispositions learned and acquired at teacher training institutes while teaching the students. Therefore, teacher training institutes are responsible to teach and develop the professional dispositions among student-teachers through teaching programs because appropriate dispositions are also essential and significant for engaging students in an effective teaching learning process for their betterment.

\section{Rationale of the Study}

In 2002, by an Ordinance Higher Education Commission (HEC) was given powers to establish different councils to improve the quality of education, so National Accreditation Council for Teacher Education (NACTE) was constituted in 2007 as an autonomous organization to improve the quality of teachers as well as teachers' programs both in public and private teacher training institutes. In Pakistan, accreditation is mandatory for all those public and private institutions that offer teacher education programs and award the degree to prospective teachers for joining the teaching profession. These institutions are responsible to inculcate, assess and document knowledge, teaching skills and professional disposition of pre-service teachers. These institutes are assessing and documenting content knowledge and teaching skills but there is no documented evidence either professional dispositions are being taught or not. This situation necessitates the current study; therefore, the researchers are interested in examining and analyzing the professional dispositions taught to prospective teachers to make sure whether pre-service teachers are being equipped with dispositions in accordance with NPSTP before joining the teaching profession as a career.

\section{Objectives}

The following were the main objectives of the study.

1. To examine the professional dispositions taught to prospective teachers.

2. To analyze the differences in the professional dispositions taught to prospective teachers on the basis of different demographics.

3. To find out the relationship between professional dispositions taught to prospective teachers and academic achievements.

\section{Research Questions}

The following were the research questions of the study.

1. Are the professional dispositions being taught to prospective teachers equally in public universities?

2. Do professional dispositions taught to prospective teachers differ on the basis of teaching programs, gender, locality, monthly family income and public universities?

3. Is there relationship between professional dispositions and prospective teachers' academic achievements?

\section{Literature Reviewed}

Professional dispositions and teacher education both are linked and essential for each other. Without teacher education or teaching programs, professional dispositions could not be taught and developed among pre-service teachers. Similarly, without dispositions teacher education is merely a combination or mixture of knowledge, facts and skills but to teach in today's school, dispositions are considered important along with theories and teaching skills. Johnston, Almerico, Henriott and Shapiro (2011) described that prospective teachers should start to consider themselves as educators to teach the students during teaching programs. According to Thornton (2006), teacher training institutes should take responsibility to teach and develop professional dispositions among pre-service teachers along with content knowledge and teaching skills. Therefore, it is needed that trainee teachers should be encouraged and supported in developing the desired behaviors and dispositions among themselves to enter the recently selected teaching profession to act accordingly what is being expected of them (Johnston et al., 2011; Schussler, Stooksberry \& Bercaw 2010). 
Wadlington and Wadlington (2011) elaborated that teacher training institutes should support the prospective educators in making them aware regarding the professional dispositions through teaching programs with preliminary courses continuing to the final courses and practicum. According to Edwards (2011), teaching programs and teaching courses offered by the teacher training institutes are committed to enhancing the understandings of upcoming educator workforce. Teacher training institutes are developing pre-service teachers, but the most important purpose is to develop them both in theory and practice to make them effective teachers. Every teaching program has content knowledge and teaching skills as essential parts of the teaching program, but professional dispositions are comparatively a new concept which was introduced by Katz \& Raths in 1985. Now professional dispositions are also considered an essential part of the teaching program because many teacher training institutes in the world are preparing their pre-service teacher according to some national or state standards and these standards are comprised of content knowledge, teaching skills and professional dispositions.

Feiman-Nemser and Schussler (2010) described that dispositions could not be isolated from the knowledge and teaching skills because dispositions are taught and developed along with content knowledge and teaching skills. Dottin (2009) argued that it is the responsibility of teaching programs to find ways for teaching, nurturing, developing and measuring the dispositions so that prospective teachers could use the developed dispositions to behave professionally according to the teaching context. Boyce (2008) also suggested that professional dispositions of prospective teachers could be changed, reformed and developed during teaching programs.

According to Ruitenberg (2011), once it has been decided that particular dispositions would be cultivated among pre-service teachers then it is necessary to consider and search ways through which the required dispositions would be taught and developed among pre-service teachers. According to Rivera (2016), if teaching programs provide admissions to those prospective educators who do not possess the essential dispositions, then teaching programs should offer training and coaching to prospective teachers to learn and develop dispositional qualities by reducing their shortcomings. Rivera (2016) further described that if teacher educators, university professors and other professionals help prospective teachers in the transformation of beliefs with respect to teaching then this would help prospective teachers to develop and acquire different teaching methods consistent with the varying needs of schoolchildren.

Many researchers argued, although development of professional dispositions as well as strategies to develop these in prospective teachers are very important but there is a lack of empirical evidences on the strategies to develop dispositions (Rose, 2013; Schussler et al., 2010). Katz (1993) considered dispositions as an essential component of prospective teachers and proposed that dispositions of pre-service teacher could be supported and strengthened since mere acquirement of content knowledge and teaching skills did not provide any assurance that prospective teachers would likely to apply in real situations. The development of prospective teachers' professional dispositions requires a well-established assessment system through which weaker dispositions can be identified in order to enhance the weaker dispositions during the teaching program.

Pang, Nichols, Terwilliger and Walsh (2014) established an assessment system to assess prospective teachers' dispositions of a public university. The core objective of the assessment system was to increase the efficiency of the teaching programs by focusing on student-teachers' dispositions. The researchers administered their research instrument during the last semester and during the teaching practice. When dispositional assessment data were analyzed, it revealed that there were found positive professional dispositions among prospective teachers during the stay at university.

Rinaldo et al. (2009) investigated either prospective teachers' perceptions and perspectives change over time or not at the master level. The data was collected using a research instrument having 21 items on a 5-point Likert-type scale. After analyzing data, the researchers found remarkable changes in the perceptions of student-teachers towards professional commitment. They further explained that they could not determine whether the occurred changes were due to content knowledge which was taught to prospective teachers in the classroom or due to clinical experience. Overall results of the study discovered that student-teachers' beliefs and perceptions were affected positively by the teacher training programs in the university.

Rike and Sharp (2008) developed a checklist to assess the prospective teachers' dispositions. For the development of the checklist, first of all, they found a defined definition of dispositions by the 
faculty and then they searched the literature and found twenty-five appropriate indicators for teachers' dispositions. They also defined the criteria to assess the dispositions. To validate the instrument, they sought opinions of 125 principals of the related area. In the light of opinions given by the principals, nine out of twenty-five indicators were selected as most important. To aware the students about the clear definition of dispositions and the criteria to assess the dispositions, a specific class was arranged, and details were shared with students. Student-teachers were also provided a copy of the checklist. During the program, students were kept engaged in repeated discussions with the teacher educators about the use of checklist to assess the dispositions. After the implementation of the checklist researchers concluded that prospective teachers found many opportunities to examine and study their progress of dispositional development throughout their stay in the teacher training program.

Waddell and Griffin (2007) conducted a research study and developed an instrument entitled "Dispositions Rating Scale" (DRS) to examine the prospective teachers' dispositions. Both the researchers conducted the study on 26 and 33 participants enrolled in the elementary education program and directed teaching program, respectively. Pre-service teachers completed a selfassessment instrument while the teacher educators, cooperating teachers and other staff who were involved in supervising the student-teachers' were given an assessment instrument to complete regarding candidates' dispositions. The researchers found that student-teachers of both the programs assessed their own dispositions higher on each statement measuring dispositions while their teacher educators' ratings were dispersed. The researchers also found that student-teachers registered in directed teaching program rated themselves higher than their teacher educators. However, no differences were observed among the ratings of future teachers registered in the elementary education program. Moreover, Waddell and Griffin (2007) found a significant change between student-teachers' scores at the start of the program and in the end of the program. On the basis of results both the researchers concluded that teaching programs had a great impact on the development of prospective teachers' professional dispositions.

\section{Methodology}

The quantitative survey research design was employed to accomplish the current research study. The population of the study was all the prospective teachers studying and getting training at departments of education of public universities of Punjab. The accessible population for the present research study was 1592 prospective teachers of the final semester of M.A Education, session 2017-19 and BS Education/B. Ed. Honors, session 2015-19 at departments of education of public universities of Punjab. The sample was selected through multi-stage sampling; public universities were selected randomly through balloting in the first stage and in the second stage census sampling technique was used to select the prospective teachers. Hence, researchers collected data from 1061 prospective teachers. In order to collect the required data, a questionnaire was developed keeping in view the dispositions described in the document of National Professional Standards for Teachers in Pakistan (NPSTP). The questionnaire was consisted of 98 items and its validity was ensured through experts' opinions whereas, reliability was ensured through pilot testing and the value of Cronbach's alpha was calculated .92. The researchers themselves visited public universities and collected the required data. Descriptive and inferential statistics were employed while analyzing the data.

\section{Data Analysis and Findings}

When the analysis was performed on prospective teachers' different demographics it was found that majority of the prospective teachers $(56.6 \%)$ were from M. A. Education. Gender wise analysis showed that the majority $(82.7 \%)$ of the pre-service teachers were female. Locality wise distribution showed that the majority $(65.3 \%)$ of the pre-service teachers were from urban areas. Cumulative Grade Point Average (CGPA) wise distribution showed that the majority (55.2\%) of the prospective teachers had CGPA between the range 3.01 to 3.50 .

Table 1

Ranking of dispositions taught to pre-service teachers on categories based on NPSTP

\begin{tabular}{llll}
\hline Category & \multicolumn{2}{l}{ Dispositions taught to prospective teachers } \\
\cline { 2 - 4 } & Mean & $S D$ & Rank \\
\hline Moral Values & 3.99 & 0.63 & 1 \\
Commitment to Students' Learning & 3.95 & 0.62 & 2 \\
Collaboration & 3.93 & 0.58 & 3 \\
Enthusiasm/Passion for Teaching & 3.90 & 0.57 & 4 \\
\hline
\end{tabular}




\begin{tabular}{llll}
\hline Critical Thinking & & & \\
Belief that all students can learn & 3.90 & 0.67 & 4 \\
Fair Assessment & 3.89 & 0.56 & 5 \\
Commitment to Problem Solving & 3.90 & 0.68 & 4 \\
Diversity & 3.88 & 0.61 & 6 \\
\hline
\end{tabular}

Table 1 displays the mean and standard deviation of professional dispositions taught to prospective teachers on dispositional categories that emerged from NPSTP. It is found that dispositions related to categories "moral values and diversity" are being taught to prospective teachers more and less respectively during teaching programs.

Table 2

Comparing dispositions taught to prospective teachers on the basis of teaching program

\begin{tabular}{llllrrrr}
\multicolumn{1}{c}{ Variable } & Program of study & $N$ & Mean & $S D$ & $t$ & $d f$ & Sig. \\
\hline Taught & M.A. Education & 600 & 385.7800 & 48.93181 & 2.118 & 1059 & .034 \\
Dispositions & BS/B. Ed. Hons & 461 & 379.4555 & 47.26480 & & &
\end{tabular}

Table 2 displays a significant difference between the professional dispositions taught to prospective teachers from M. A. Education $(M=385.7800, S D=48.93181)$ and pre-service teachers from BS/B. Ed. Honors $(M=379.4555, S D=47.26480), t=2.118, p=<.05$. It is found that pre-service teachers of M. A. Education perceived that professional dispositions are being more taught as compared to prospective teachers of BS/B. Ed. Honors in Education.

Table 3

Comparing dispositions taught to prospective teachers on the basis of gender

\begin{tabular}{|c|c|c|c|c|c|c|c|}
\hline Variable & Program of study & $N$ & Mean & $S D$ & $t$ & $d f$ & Sig. \\
\hline Taught & Male & 184 & 380.9239 & 46.88918 & -.651 & 1059 & .515 \\
\hline Dispositions & Female & 877 & 383.4743 & 48.59812 & & & \\
\hline
\end{tabular}

Table 3 displays no significant difference between dispositions taught to male $(M=380.9239$, $S D=46.88918)$ and female pre-service teachers $(M=383.4743, S D=48.59812), t=-.651, p=<.05$; and there was found no significant difference between professional dispositions taught to male and female prospective teachers.

Table 4

Comparing dispositions taught to prospective teachers on the category critical thinking on the basis of locality

\begin{tabular}{llrrrrcc}
\hline \multicolumn{1}{c}{ Variable } & Locality & $N$ & Mean & $S D$ & $t$ & $d f$ & Sig. \\
\hline Taught & Rural & 368 & 26.8995 & 4.82536 & -2.082 & 1059 & .038 \\
Dispositions & Urban & 693 & 27.5253 & 4.56912 & & & \\
\hline
\end{tabular}

Table 4 displays a significant difference between professional dispositions taught to prospective teachers from rural areas $(M=26.8995, S D=4.82536)$ and prospective teachers belonging to urban areas $(M=27.5253, S D=4.56912), t=-2.082, p=<.05$ regarding critical thinking. It is found that prospective teachers from urban areas perceived that more dispositions regarding critical thinking are being taught as compared to prospective teachers from rural areas.

Table 5

Comparing dispositions taught to prospective teachers on the basis of monthly family income

\begin{tabular}{clllll}
\hline Variable & \multicolumn{1}{c}{ Variance } & $d f$ & $F$ & Sig. \\
\hline Taught Dispositions & Between Groups & 4 & .799 & .526 \\
& Within Groups & 1056 & & \\
& Total & 1060 & & \\
\hline
\end{tabular}

Table 5 displays no significant difference in the dispositions taught to prospective teachers on the basis of monthly family income $F(4,1056)=.799$, but when LSD post hoc test was applied it produced some differences. Following table shows the LSD post hoc test results for above mentioned comparison.

Table 6

LSD post hoc comparison on the basis of family monthly income

\begin{tabular}{cccccc}
\hline Dependent Variable & $\begin{array}{c}\text { (I) Monthly } \\
\text { Family Income }\end{array}$ & $\begin{array}{c}\text { (J) Monthly } \\
\text { Family Income }\end{array}$ & Mean Difference (I-J) & Std. Error & Sig. \\
\hline Taught Dispositions & Up to 20000 & Up to 80000 & 2.14993 & .99340 & .031 \\
& Up to 40000 & Up to 80000 & 2.03328 & .94213 & .031 \\
\hline
\end{tabular}


Table 6 shows that pre-service teachers having monthly family income up to 20,000 and up to 40,000 , depicted that they had been taught significantly more dispositions regarding diversity than that of pre-service teachers having monthly family income up to 80,000 .

Table 7

Comparing dispositions taught to prospective teachers on the basis of universities

\begin{tabular}{llllll}
\multicolumn{1}{c}{ Variable } & \multicolumn{1}{c}{ Region } & \multicolumn{1}{c}{ Variance } & $d f$ & $F$ & Sig. \\
\hline Taught & South Punjab & Between Groups & 6 & 3.944 & .001 \\
Dispositions & & Within Groups & 334 & & \\
& & Total & 340 & & \\
& Central Punjab & Between Groups & 8 & 2.083 & .035 \\
& & Within Groups & 658 & & \\
& & Total & 666 & & \\
\hline
\end{tabular}

Table 7 displays a significant difference in the dispositions taught to prospective teachers on the basis of public universities of South Punjab $F(6,334)=3.944, p<.05$; and table also displays a significant difference on the basis of public universities of Central Punjab $F(8,658)=2.083, p<.05$. It means that significant differences are found in the professional dispositions taught to prospective teachers on the basis of public universities of Punjab. Pre-service teachers from Ghazi University of South Punjab depicted that they are being taught more dispositions than pre-service teachers at other public universities of the region. Similarly, prospective teachers from the University of Education, Jouhrabad campus of Central Punjab depicted that they are being taught more dispositions than preservice teachers at other public universities of the region.

Table 8

Pearson Correlation between dispositions taught to pre-service teachers and CGPA

\begin{tabular}{lcc}
\hline Variable & Taught Dispositions & CGPA \\
\hline Taught Dispositions & 1 & \\
CGPA & $.061^{*}$ & 1 \\
\hline
\end{tabular}

$* \mathrm{p}<0.05, \mathrm{~N}=1061$

Table 8 displays that dispositions taught to pre-service teachers and their academic achievements (CGPA) are significantly positively correlated $\mathrm{r}=.061, p=<.05$. There was found a positive correlation between dispositions taught to prospective teachers and academic achievements (CGPA).

\section{Discussion}

In the existing research study, overall, some prominent differences were observed on professional dispositions taught to pre-service teachers. According to the responses of prospective teachers, the categories "moral values" and "commitment to students' learning" were ranked $1^{\text {st }}$ and $2^{\text {nd }}$ respectively. Pre-service teachers reflected that they were taught more the same dispositions i.e., moral values and commitment to students' learning as compared to other categories. The possible reason for ranking "moral values" and "commitment to students' learning" in $1^{\text {st }}$ and $2^{\text {nd }}$ place were due to the teaching of these dispositions through different courses. It is also possible that the teaching profession demands from teachers to follow moral values and commitment to students' learning. As the majority of the universities do not have laboratory schools in Pakistan where prospective teachers could be placed for teaching practice. When prospective teachers are placed in public and private schools for the purpose of teaching practice; they are directly assigned classes to teach. Therefore, prospective teachers have to work hard for enhancing students' learning while following some general and school-based moral and ethical values already established. Therefore, prospective teachers considered moral values and commitment to students' learning most important. Pauli (2006) concluded that dispositions "honesty and caring" acquired $1^{\text {st }}$ and $2^{\text {nd }}$ highest rating respectively whereas dispositions "effective communication" were placed at the lowest level in the ratings by faculty members, cooperating teachers and pre-service teachers. Pauli (2006) further elaborated that indicators "collaboration" and "enthusiasm/passion for teaching" were in the third position. On the contrary, Brittenum (2015) concluded that dispositions related to communication and respect were ranked second and third respectively according to the preferences of teachers.

Professional dispositions related to categories "critical thinking", "belief that all students can learn" and "fair assessment" were placed on $4^{\text {th }}, 5^{\text {th }}$ and $6^{\text {th }}$ positions, respectively. Beliefs that all students can learn are important dispositions as Schussler and Knarr (2013) claimed that these are 
teachers' dispositions that explain their beliefs to use best teaching practices for students according to situations. For example, if a teacher believes that students should be taught equally in the class while another teacher believes that students should be taught according to students' needs and talents both the teachers will adopt different teaching strategies in the class. Likewise, dispositions related to "commitment to problem-solving" and "diversity" were placed on the lowest ratings, respectively. It means prospective teachers depicted that they are being taught a smaller quantity of professional dispositions with respect to these categories (commitment to problem solving and diversity) as compared to other categories. The possible reason is that prospective teachers are not being taught how to deal with students equitably or how to address the diverse needs of students according to the cultural and religious perspectives. It might be these dispositions are not included in the curriculum, whatever the reasons are, it requires further research.

On the basis of teaching programs, results revealed that prospective teachers from the program M.A. Education were being taught more professional dispositions as compared to pre-service teachers from the programs BS/B. Ed. Honors in Education. It might be due to the reason that prospective teachers from the program M.A. Education are more enthusiastic to join the teaching profession therefore, they projected themselves on the questionnaire because some prospective teachers from the programs BS and B. Ed. Honors in Education professed that they would not be teachers in the future as they join the teaching program by chance, not by choice.

On the basis of gender, no significant difference was observed and this may be due to the reason that the same curriculum is being taught by the same teachers in the same institutions under one roof having the same teaching-learning environment. On the basis of locality, overall results revealed no significant results among pre-service teachers' professional dispositions taught to them; however, an important significant result was noted on the category "critical thinking". Prospective teachers from urban areas depicted that they were being taught more professional dispositions about critical thinking than prospective teachers from rural areas. Some researchers reported that future teachers who worked under the supervision of their mentor teachers in urban school settings during teaching practice developed more professional dispositions among themselves (Darling-Hammond, Chung \& Frelow, 2002).

On the basis of family monthly income, indicator wise results for the category "diversity" revealed that pre-service teachers whose family monthly income was ranging from 20,000 to 40,000 depicted more taught dispositions than pre-service teachers whose family monthly income was up to 80,000 . Prospective teachers having low family income are more focusing on professional dispositions regarding diversity in their respective teaching programs to address the issues of students' multiplicity. Hence, pre-service teachers with low family income are ready to welcome diversity in schools and it is a good sign for improving the school environment.

On the basis of public universities of Punjab, prominent differences were observed. Student teachers from Ghazi University (a small institute having 2.7\% teacher candidates) and the University of Education, Jouhrabad Campus (also a small institute having $1.6 \%$ teacher candidates) depicted more taught dispositions than pre-service teachers from other universities of Punjab. Baldwin (2007) reported that larger teacher training institutes tend to teach more dispositions as compared to smaller institutes which are teaching fewer dispositions whereas Kirchner (2011) found no significant differences among student teachers of larger and smaller institutions on dispositions taught to student teachers. But according to the respondents of the present study it has been revealed that smaller teacher training institutions are teaching more professional dispositions.

A positive correlation was found between professional dispositions taught to prospective teachers and academic achievements (CGPA). It means teaching more dispositions helps prospective teachers to enhance their academic achievements as well as to develop more dispositions. But dispositions are not being adequately taught in universities therefore, dispositions should be included more in the curriculum of teaching programs. Whatever the reasons are but it is a fact that in Pakistan, prospective teachers are being taught in the traditional way (assignments, presentations, mid-term test, final test) as other subjects of different disciplines (e.g. Urdu, English, History, Economics etc.) are being taught to students in the universities except for teaching practice which is only meant for prospective teachers. No deliberate struggle is being made to teach and develop prospective teachers' dispositions to make them effective for the future. Student-teachers are not made aware by teacher educators to develop the dispositions mentioned in the NPSTP. Therefore, there should be deliberate 
efforts in teacher training institutes to teach and develop the required dispositions among prospective teachers.

\section{Conclusions}

The present study concluded that in teacher training institutions, all the required dispositions mentioned in NPSTP are not being taught and hence, prospective teachers depicted those dispositions more which are included in the curriculum and are being taught to prospective teachers in their respective teaching programs. For example courses "Educational Psychology" and "Teaching Methods" develop dispositions which help prospective teachers to use a variety of instructional strategies according to the needs of students and the situation of the class that is why prospective teachers depicted more taught dispositions regarding commitment to students' learning as compared to other categories. As per NACTE's manual, teachers training institutes are responsible to teach and develop dispositions in prospective teachers of Pakistan. Therefore, prospective teachers should be engaged in learning more content knowledge, teaching skills and professional dispositions in order to make them effective future teachers. In order to develop weaker dispositions (fair assessment, welcoming diversity) of prospective teachers there should be a conducive learning environment and faculty members should also display appropriate dispositions to be followed by pre-service teachers. Teacher educators' dispositions also affect prospective teachers' dispositions therefore, teacher educators should modify themselves (if necessary) to affect positive impacts on prospective teachers.

Furthermore, it is concluded that if prospective teachers are taught more dispositions then they reflect more professional dispositions. Therefore, teacher training institutions should focus to teach more and more professional dispositions in order to develop prospective teachers' dispositions. In the present study, prospective teachers were of the view that some dispositions were being taught less and hence, these dispositions should be taught more to prospective teachers by teacher training institutes. Additional content should be included in the curriculum to enhance the prospective teachers' dispositions in accordance with dispositions given in NPSTP. For this purpose, a course like professionalism in education should be focused on the curriculum of teaching programs to strengthen the weaker dispositions (e.g. accepting diversity) of prospective teachers.

It was also concluded that academic achievements (CGPA) of prospective teachers could be increased through the teaching of professional dispositions. Therefore, more planned emphasis should be given on teaching professional dispositions to prospective teachers.

\section{Recommendations}

1. Teacher training institutes should focus on weaker dispositions which are being taught less to prospective teachers such as fair assessment, commitment to problem solving and welcoming the diversity to strengthen in order to make them effective teachers. Reinforcing weaker dispositions will help the teacher candidates to work in a better way with diverse learners.

2. It is proved that teaching of dispositions helps to improve prospective teachers' dispositions. Teacher educators are considered role models. Teachers are followed by students; hence, teachers affect students' dispositions in a number of ways. Therefore, teacher educators' dispositions should also be checked. Therefore, the HEC may devise some standards especially for teacher educators in the field of teacher training to be followed. The NACTE may develop a training mechanism for teacher educators from each teacher training institute for the development of dispositions and its assessment.

3. The findings of the present study revealed that professional dispositions of prospective teachers could be improved and developed through teaching the required dispositions. Therefore, policymakers may introduce a core subject based on professional dispositions having more dispositions-oriented content. This policy may be induced by consulting all the stakeholders of teacher education for the improvement and development of future teachers' dispositions according to NPSTP.

\section{References}

Anderson, A. R., Christenson, S. L., Sinclair, M. F., \& Lehr, C. A. (2004). Check \& Connect: The importance of relationships for promoting engagement with school. Journal of School Psychology, 42(2), 95-113.

Baldwin, A. M. (2007). The curriculum, instruction, and assessment of dispositions in preservice teacher education, (Doctoral dissertation, The Andrews University). 
Boyce, J. S. (2008). The effects of strategic modeling on the development of dispositions in preservice teachers. (Doctoral dissertation, University of Southern Mississippi).

Brittenum, T. D. (2015). The relationship among motivational orientation of teachers, the leadership disposition they most prefer, and their intention to remain or leave their current teaching assignment. (Doctoral Dissertation, The University of Memphis).

Darling-Hammond, L., Chung, R., \& Frelow, F. (2002). Variation in teacher preparation: How well do different pathways prepare teachers to teach? Journal of teacher education, 53(4), 286302.

Dottin, E. S. (2009). Professional judgment and dispositions in teacher education. Teaching and teacher education, 25(1), 83-88.

Edwards, S. (2011). Developing Diversity Dispositions for White Culturally Responsive Teachers. Action in Teacher Education, 33(5-6), 493-508, DOI: 10.1080/01626620.2011.627038

Feiman-Nemser, S., \& Schussler, D. L. (2010). Defining, developing, and assessing dispositions: A cross-case analysis. Teaching as a moral practice. Defining, developing, and assessing professional dispositions in teacher education, 177-201.

Johnston, P., Almerico, G. M., Henriott, D., \& Shapiro, M. (2011). Descriptions of dispositions for assessment in pre-service teacher education field experiences. Education, 132(2).

Katz, L. G. (1993). Dispositions: Definitions and Implications for Early Childhood Practices. Perspectives from ERIC/EECE: A Monograph Series, No. 4.

Kirchner, S. (2011). First-year teachers' dispositions: exhibited and perception of being taught. (Doctoral Dissertation, Kansas State University).

Notar, C. E., Riley, G. W., Taylor, P. W., Thornburg, R. A., \& Cargill, R. L. (2009). Dispositions: Ability and assessment. International Journal of Education, (1)1, 2-14.

Pang, Y., Nichols, K., Terwilliger, C., \& Walsh, M. (2014). Assessment of Pre-service Teachers' Dispositions for Programmatic Improvement. National Teacher Education Journal, 7(1).

Parrott, M. Y., Ros-Voseles, D., Denise, A., \& Eaton, P. (2013). A Picturesque View of Dispositions, Autonomy, and Efficacy during the Educational Preparation of Early Childhood Educators. Online Submission.

Pauli, C. R. (2006). Pre-service teacher dispositions: A preliminary investigation of the perceptions of student teachers, university supervisors, and cooperating teachers after the student teaching experience (Doctoral dissertation, Capella University).

Rike, C. J., \& Sharp, L. K. (2009). Developing and assessing teacher candidates' dispositions: A beneficial process for all. Affective teacher education: Exploring connections among knowledge, skills, and dispositions, 61-77.

Rinaldo, V. J., Denig, S. J., Sheeran, T. J., Cramer-Benjamin, R., Vermette, P. J., Foote, C. J., \& Smith, R. M. (2009). Developing the Intangible Qualities of Good Teaching: A SelfStudy. Education, 130(1), 42-52.

Rivera, D. A. (2016). Working with Student Teachers: A Mixed Methods Study to Examine the Roles and Self-Identified Dispositions of Cooperating Teachers (Doctoral dissertation, University of Maryland).

Rose, S. (2013). How do teacher preparation programs promote desired dispositions in candidates?. SAGE Open, 3(1), 2158244013480150.

Ruitenberg, C. W. (2011). The trouble with dispositions: A critical examination of personal beliefs, professional commitments and actual conduct in teacher education. Ethics and Education, 6(1), 41-52.

Schussler, D. L., \& Knarr, L. (2013). Building awareness of dispositions: Enhancing moral sensibilities in teaching. Journal of Moral Education, 42(1), 71-87.

Schussler, D. L., Stooksberry, L. M. \& Bercaw, L. A. (2010). Understanding teacher candidate dispositions: Reflecting to build self-awareness. Journal of Teacher Education, 61(4), 350363.

Shoffner, M., Sedberry, T., Alsup, J., \& Johnson, T. S. (2014). The difficulty of teacher dispositions: Considering professional dispositions for preservice English teachers. The Teacher Educator, 49(3), 175-192.

Taylor, R. L., \& Wasicsko, M. M. (2000, November). The dispositions to teach. In annual meeting of the Southern Region Association of Teacher Educators (SRATE) Conference, Lexington, KY. 
Thornton, H. (2006). Dispositions in action: Do dispositions make a difference in practice? Teacher Education Quarterly, 33(2), 53-68.

Waddell, J. R., \& Griffin, L. L. (2007). An instrument for assessing teacher candidate dispositions. Paper presented the Sixth Annual Symposium on Educator Dispositions, Cincinnati, OH. Retrieved from http://coehs.nku.edu/ educatordispositions/symposium_2007/papers/instrumentforassessing.pdf

Wadlington, E., \& Wadlington, P. (2011). Teacher dispositions: Implications for teacher education. Childhood Education, 87(5), 323-326.

Wayda, V., \& Lund, J. (2005). Assessing dispositions: An unresolved challenge in teacher education. Journal of Physical Education, Recreation, \& Dance, 76(1), 34-41. 